\title{
Short Communication Role of hormonal risk factors in HER2-positive breast carcinomas
}

\author{
A Balsari', P Casalini', R Bufalino', F Berrino' and S Ménard*,2 \\ 'Istituto Nazionale Tumori, Via Venezian I, 20133 Milano, Italy and ${ }^{2}$ Chair of Immunology, University of Milan, Via Venezian I, 20133 Milano, Italy
}

Examination of parity, age at menarche and at menopause by HER2 status in a large series of breast carcinomas showed a statistically significant increased-frequency of HER2-positive tumours in lower risk subgroups. The findings suggest a difference in the protective role of hormone-related risk factors between HER2-positive and -negative tumours.

British Journal of Cancer (2003) 88, 1032 - 1034. doi:I0.1038/sj.bjc.6600844 www.bjcancer.com

(c) 2003 Cancer Research UK

Keywords: hormone factor risk; HER2; epidemiology

Clinical and molecular biology findings have led to the identification of tumour overexpressing HER2 (HER2+) as a distinct subset (comprising 20-25\%) of breast carcinomas (Slamon et al, 1989; Ross and Fletcher, 1998, 1999; Ménard et al, 2002). This subgroup is characterised by a high aggressiveness (Ferrero-Pous et al, 2000) and responsiveness to chemotherapy (Ménard et al, 1999b). Since HER2-positivity has been associated with hormone independence due to the absence of expression of hormone receptors and unresponsiveness to tamoxifen (Pietras et al, 1995; Carlomagno et al, 1996), we hypothesised that hormonal risk factors may not influence HER2-positive tumours. If this is the case, the proportion of HER2-positive tumours as part of all tumours should be higher in the protected subgroup than in the unprotected ones.

To test this hypothesis, in a large surgical database of breast carcinomas at the National Cancer Institute of Milan from 1968 to 1979, we analysed the frequency of HER2-positive tumours, determined by immunohistochemistry, according to parity and age at menarche and at menopause.

\section{PATIENTS AND METHODS}

Two series of consecutive patients treated at the Istituto Nazionale Tumori in Milan, Italy, for primary breast carcinoma were considered: first, 1211 patients who underwent surgery in $1968-$ 1969 and received no further treatment (Rilke et al, 1991) and second, 717 patients operated in $1978-1979$ and who then received adjuvant chemotherapy (Ménard et al, 1999a). The two series were very similar as concerned age at diagnosis, age at menarche, age at menopause, percent of premenopausal cases, number of children, nulliparous cases (Table 1). Only natural menopause was considered. Immunocytochemical staining was retrospectively carried out on Bouin-fixed, paraffin-embedded tissue using a polyclonal antibody against HER2-specific peptide (kindly provided by DJ Slamon), for the first series and anti-HER2 CB11 (1:10 dilution, Ylem, Avezzano, AQ, Italy) for the second series. Both

* Correspondence: Dr S Ménard;

E-mail: sylvie.menard@istitutotumori.mi.it

Received 8 October 2002; revised I 3 January 2003; accepted I 5 January 2003 antibodies revealed a $23 \%$ of HER2-positivity and an overlapping staining on consecutive slides stained with these two reagents (Mezzelani et al, 1999).

The proportion of HER2-positive tumours was analysed, according to parity (1655 cases) and age at menarche (1692 cases) and at menopause (1050 cases). The subgroup with 0 or 1 child, and the subgroups of $<12$ or $<45$, respectively, for age of menarche and age of menopause were considered as control group $(\mathrm{OR}=1)$. The expected proportions (EP) of HER2-positivity were calculated assuming that HER2-positive tumours are not affected by hormonal risk factors and using the mean odds ratios (OR) reported for parity, ages at menarche and menopause (Brinton et al, 1988; Vatten and Kvinnsland, 1992; Kelsey et al, 1993).

Expected proportions were defined as HER2-positive frequency of control group divided by mean OR reported in the literature for the risk group considered. Differences in proportions were analysed using the $\chi^{2}$ test.

\section{RESULTS}

The first step in the analysis considered the effect of parity on HER2-positive breast cancer risk. The proportion of HER2positive tumours was found to vary from $20.9 \%$ in the group with zero or one child, to $23.8 \%$ in the group with two or three children, up to $30.5 \%$ for women with more than three children (Table 2). The significant increase of frequency $\left(P=0.03, \chi^{2}\right.$-test) of HER2positive tumours, according to the parity, suggests that this factor protects only the HER2-negative tumours. Accordingly, assuming protection only for the HER2-negative tumour subset and using the ORs as described in Patients and Methods for parity, the expected proportions of HER2-positivity would be of 20.9, 22.0 and $27.9 \%$ in the respective groups, that is, quite similar to the observed frequencies (Table 2).

The two other hormonal risk factors for breast carcinomas recorded in our database, that is, ages at menarche and menopause, also appear to have a protective impact only on HER2-negative tumours. In fact, an increased HER2-positive tumour proportion was observed with increased age at menarche, which is associated with decreased risk, and a decrease in HER2positivity was observed with increased age at menopause, which is 
Table I Characteristics of the two cohorts included in the analysis

\begin{tabular}{|c|c|c|c|c|}
\hline \multirow{2}{*}{$\begin{array}{l}\text { Parameter } \\
\text { Mean age at diagnosis (range) }\end{array}$} & \multicolumn{2}{|c|}{$\begin{array}{l}\text { First series } \\
\text { I } 2 \text { I I patients }\end{array}$} & \multicolumn{2}{|c|}{$\begin{array}{l}\text { Second series } \\
717 \text { patients }\end{array}$} \\
\hline & $55(2|-8|)$ & $\left.|2|\right|^{\mathrm{a}}$ & $53(25-84)$ & $717^{\mathrm{a}}$ \\
\hline Mean age at menarche (range) & $13(10-20)$ & $1002^{\mathrm{a}}$ & $13(7-19)$ & $690^{a}$ \\
\hline Mean age at natural menopause (range) & $49(30-62)$ & $649^{a}$ & $48(27-77)$ & $401^{\mathrm{a}}$ \\
\hline Frequency of premenopausal cases & $39 \%$ & $\left.121\right|^{\mathrm{a}}$ & $43 \%$ & $717^{\mathrm{a}}$ \\
\hline Mean number of children (range) & $1.6(0-8)$ & $970^{\mathrm{a}}$ & $1.8(0-\mid 1)$ & $685^{a}$ \\
\hline Frequency of nulliparous cases & $22 \%$ & $970^{\mathrm{a}}$ & $22 \%$ & $685^{a}$ \\
\hline Frequency of HER2-positivity & $23 \%$ & $\left.|2|\right|^{\mathrm{a}}$ & $23 \%$ & $717^{\mathrm{a}}$ \\
\hline
\end{tabular}

${ }^{a}$ Number of patients considered for series.

Table 2 Frequency of HER2-positivity in primary breast carcinomas according to parity, ages at menarche and menopause of the patients

\begin{tabular}{|c|c|c|c|c|c|}
\hline Groups & $\begin{array}{l}\text { No. of } \\
\text { cases }\end{array}$ & $\begin{array}{c}\text { No. of } \\
\text { HER2+ cases }\end{array}$ & $\begin{array}{l}\text { Observed } \\
\% \text { HER2+ }\end{array}$ & $\begin{array}{l}\text { OR Mean from } \\
\text { literature }\end{array}$ & $\begin{array}{c}\text { Expected \% HER2+ } \\
\text { considering no protection for } \\
\text { HER2+ tumours }\end{array}$ \\
\hline $0-1$ & 805 & 168 & 20.9 & 1 & 20.9 \\
\hline $2-3$ & 709 & 169 & $23.8 *$ & 0.95 & 22.0 \\
\hline$>3$ & $|4|$ & 43 & $30.5 *$ & 0.75 & 27.9 \\
\hline $12-13$ & 806 & 184 & 22.8 & - & \\
\hline$>13$ & 639 & 158 & 24.7 & 0.85 & 25.2 \\
\hline \multicolumn{6}{|l|}{ Menopause } \\
\hline$<45$ & 194 & 45 & 23.2 & 1 & 23.2 \\
\hline $45-49$ & 298 & 68 & 22.8 & - & \\
\hline
\end{tabular}

* $P=0.03$ by $\chi^{2}$. OR $=$ Odds ratio.

associated with increased risk (Table 2). Again using the estimated ORs and assuming protection only for HER2-negative tumours, the expected frequencies of HER2-positivity are in the range of the observed ones (Table 2).

\section{DISCUSSION}

Altogether our analyses suggest that the three hormone-related risk factors analysed seem to protect only HER2-negative tumour subset. These results may be interpreted also as opposite to a promoting effect of hormone-related risk factors for the HER2positive subgroup. Indeed, some clinical data (Carlomagno et al, 1996) have suggested a detrimental effect of tamoxifen treatment in patients with HER2-positive tumours.

\section{REFERENCES}

Brinton LA, Schairer C, Hoover RN, Fraumeni JFJ (1988) Menstrual factors and risk of breast cancer. Cancer Invest 6: 245-254

Carlomagno C, Perrone F, Gallo C, De Laurentiis M, Lauria R, Morabito A, Pettinato G, Panico L, D’Antonio A, Bianco AR, De Placido S (1996) c-erbB2 overexpression decreases the benefit of adjuvant tamoxifen in early-stage breast cancer without axillary lymph node metastases. J Clin Oncol 14: $2702-2708$

Ferrero-Pous M, Hacene K, Bouchet C, Le Doussal V, Tubiana-Hulin M, Spyratos F (2000) Relationship between c-erbB-2 and other
To date, the majority of risk factors for breast carcinomas identified are related to hormones. Identification of other risk factors, specific for the onset of HER2-positive tumours might be hampered by a clouding effect of HER2-negative tumours, which represent the great majority of breast carcinomas. Indeed, as long as HER2-positive tumours, which represent only $25 \%$ of cases and therefore of little weight among all breast carcinomas, are analysed together with the negative ones, it will be difficult to sort out risk factors for HER2-positive tumours.

In conclusion, our study suggests that HER2-negative and -positive tumour subsets are influenced differently by breast carcinoma hormone-related risk factors. To confirm these data, a cohort study specifically addressing the role of hormone risk-factors for breast cancer with respect to HER2 status is going on. tumor characteristics in breast cancer prognosis. Clin Cancer Res 6: $4745-4754$

Kelsey JL, Gammon MD, John EM (1993) Reproductive factors and breast cancer. Epidemiol Rev 15: 36-47

Ménard S, Balsari A, Casalini P, Tagliabue E, Campiglio M, Bufalino R, Cascinelli N (2002) HER2-positive breast carcinomas as a particular subset with peculiar clinical behaviors. Clin Cancer Res 8: 520-525

Ménard S, Casalini P, Tomasic G, Pilotti S, Cascinelli N, Bufalino R, Perrone F, Longhi C, Rilke F, Colnaghi MI (1999a) Pathobiologic identification of 
two distinct breast carcinoma subsets with diverging clinical behaviors. Breast Cancer Res Treat 55: 169-177

Ménard S, Valagussa P, Pilotti S, Biganzoli E, Boracchi P Casalini P, Tomasic G, Marubini E, Colnaghi MI, Cascinelli N, Bonadonna G. (1999b) Benefit of CMF treatment in lymph nodepositive breast cancer overexpressing HER2. Proc Am Soc Clin Oncol 18: 257

Mezzelani A, Alasio L, Bartoli C, Bonora MG, Pierotti MA, Rilke F, Pilotti S (1999) c-erbB2/neu gene and chromosome 17 analysis in breast cancer by FISH on archival cytological fine-needle aspirates. $\mathrm{Br} \mathrm{J}$ Cancer 80: 519-525

Pietras RJ, Arboleda J, Reese DM, Wongvipat N, Pegram MD, Ramos L, Gorman CM, Parker MG, Sliwkowski MX, Slamon DJ (1995) HER-2 tyrosine kinase pathway targets estrogen receptor and promotes hormone-independent growth in human breast cancer cells. Oncogene 10: $2435-2446$
Rilke F, Colnaghi MI, Cascinelli N, Andreola S, Baldini MT, Bufalino R, Della Porta G, Ménard S, Pierotti MA, Testori A (1991) Prognostic significance of HER-2/neu expression in breast cancer and its relationship to other prognostic factors. Int J Cancer 49: 44-49

Ross JS, Fletcher JA (1998) The HER-2/neu oncogene in breast cancer: prognostic factor, predictive factor, and target for therapy. The Oncologist 3: 237-252

Ross JS, Fletcher JA (1999) HER-2/neu (c-erb-B2) gene and protein in breast cancer. Am J Clin Pathol 112: S53-S67

Slamon DJ, Godolphin W, Jones LA, Holt JA, Wong SC, Keith DE, Levin WJ, Stuart SG, Udove J, Ullrich A, Press MF (1989) Studies of the HER-2/ neu proto-oncogene in human breast and ovarian cancer. Science 244: $707-712$

Vatten LJ, Kvinnsland S (1992) Pregnancy-related factors and risk of breast cancer in a prospective study of 29,981 Norwegian women. Eur J Cancer 28A: $1148-1153$ 